OPEN ACCESS

Edited by:

Peter Bader,

University Hospital Frankfurt, Germany

Reviewed by:

Joerg Halter,

University of Basel, Switzerland

Evelyn Ullrich,

Goethe University Frankfurt, Germany

*Correspondence:

Antonio Pierini

antonio.pierini@unipg.it

${ }^{\dagger}$ These authors have contributed equally to this work and share first authorship

Specialty section:

This article was submitted to Alloimmunity and Transplantation,

a section of the journal

Frontiers in Immunology

Received: 14 April 2021

Accepted: 06 July 2021

Published: 03 August 2021

Citation:

Limongello R, Marra A, Mancusi A, Bonato S, Hoxha E, Ruggeri L, Hui S, Velardi A and Pierini A (2021)

Novel Immune Cell-Based

Therapies to Eradicate High-Risk

Acute Myeloid Leukemia.

Front. Immunol. 12:695051.

doi: 10.3389/fimmu.2021.695051

\section{Novel Immune Cell-Based Therapies to Eradicate High-Risk Acute Myeloid Leukemia}

\author{
Roberto Limongello ${ }^{1 \dagger}$, Andrea Marra ${ }^{1+}$, Antonella Mancusi ${ }^{1}$, Samanta Bonato ${ }^{1}$, \\ Eni Hoxha ${ }^{1}$, Loredana Ruggeri ${ }^{1}$, Susanta Hui ${ }^{2,3}$, Andrea Velardi ${ }^{1}$ and Antonio Pierini ${ }^{1 *}$

\begin{abstract}
1 Institute of Hematology and Centre of Haemato-Oncology Research (CREO), University and Hospital of Perugia, Perugia, Italy, ${ }^{2}$ Department of Radiation Oncology, City of Hope Medical Center, Duarte, CA, United States, ${ }^{3}$ Beckman Research Institute of City of Hope, Duarte, CA, United States
\end{abstract}

Adverse genetic risk acute myeloid leukemia (AML) includes a wide range of clinicalpathological entities with extremely poor outcomes; thus, novel therapeutic approaches are needed. Promising results achieved by engineered chimeric antigen receptor (CAR) T cells in other blood neoplasms have paved the way for the development of immune cellbased therapies for adverse genetic risk AML. Among these, adoptive cell immunotherapies with single/multiple CAR-T cells, CAR-natural killer (NK) cells, cytokine-induced killer cells (CIK), and NK cells are subjects of ongoing clinical trials. On the other hand, allogeneic hematopoietic stem cell transplantation (allo-HSCT) still represents the only curative option for adverse genetic risk AML patients. Unfortunately, high relapse rates (above 50\%) and associated dismal outcomes (reported survival 10$20 \%$ ) even question the role of current allo-HSCT protocols and emphasize the urgency of adopting novel effective transplant strategies. We have recently demonstrated that haploidentical allo-HSCT combined with regulatory and conventional T cells adoptive immunotherapy (Treg-Tcon haplo-HSCT) is able to overcome disease-intrinsic chemoresistance, prevent leukemia-relapse, and improve survival of adverse genetic risk AML patients. In this Perspective, we briefly review the recent advancements with immune cell-based strategies against adverse genetic risk AML and discuss how such approaches could favorably impact on patients' outcomes.

Keywords: HR-AML, poor outcome, adoptive immune therapies, CAR-T, HSCT, Treg-Tcon

\section{INTRODUCTION}

High risk (or adverse risk) acute myeloid leukemias (HR-AML) include a number of clinical and biological AML subsets which are usually characterized by poor response to conventional treatments and dismal long-term survival, even when conventional allogeneic hematopoietic stem cell transplantation (allo-HSCT) is performed (1). Such AML category is characterized by high-risk cytogenetics [i.e., complex and/or monosomal karyotypes, chromosomes 3, 5, 7, and 17 aberrations) and/or by specific genetic signatures (including mutations in TP53, RUNX1, ASXL1, and FLT3 genes (2)] that confer an aggressive phenotype and often chemoresistance. Moreover, a 
large proportion of patients affected by secondary AML (sAML) (3) and therapy-related leukemias (tr-AML) (4) converge into the HR-AML category. sAML is characterized by distinct molecular features, frequently involving the aberrant displacement of spliceosomal machinery (SRSF2, SF3B1, $U 2 A F 1$, and ZRSR2), epigenetic modifiers (ASXL1, EZH2, $B C O R, R U N X 1$ ), and cell-cycle regulators (TP53) (2). Despite the fact that next-generation sequencing (NGS) analyses have recently shed some light on the genetic complexity of these AML subsets, deep knowledge on leukemogenesis of each specific biological entity is currently lacking. Thus, targeted therapeutic approaches are still missing. While several drugs have been recently approved for the treatment of adult AML, they have only shown to slightly influence the fatal course of HR-AML patients. Such expanding armamentarium includes small molecules (e.g., FLT3 inhibitors, Midostaurin and Gilteritinib; isocitrate-dehydrogenase type 1 and 2/IDH1-2 inhibitors, Ivosidenib and Enasidenib; the Bcl2-inhibitor, Venetoclax) and new-generation cytotoxic treatments, like CPX-351 (5). Indeed, CPX-351 received Food and Drug Administration (FDA) 2019 approval for the treatment of tr-AML or AML with myelodysplasia-related changes (AML-MRC). Furthermore, emerging tailored strategies against mutant TP53 (i.e., APR246, Pevonedistat) (6-9) are providing encouraging yet preliminary evidences that may support their use in this highrisk setting. Since the achievement of durable remissions and the prevention of disease relapse remain major issues in the treatment of these patients, many research efforts have been directed towards a deeper understanding of mechanisms regulating relapse biology, with a major focus on immune system perturbation.

Immune-based adoptive cell therapies (ACTs) rely on the infusion of immune cells that aim to kill the tumor. These therapeutic platforms are revolutionizing treatment of blood neoplasms (Figure 1) and are challenging traditional drug interventions (10). In recent years, important advances have been made in developing novel effective immunotherapies (immune-checkpoint blockade, ACT, and vaccines) to overcome tumor-induced T-cell exhaustion and immune escape (10). Chimeric antigen receptor T-cells (CAR-T cells) are a form of ACT that has already demonstrated to be an effective treatment of various aggressive cancers, including

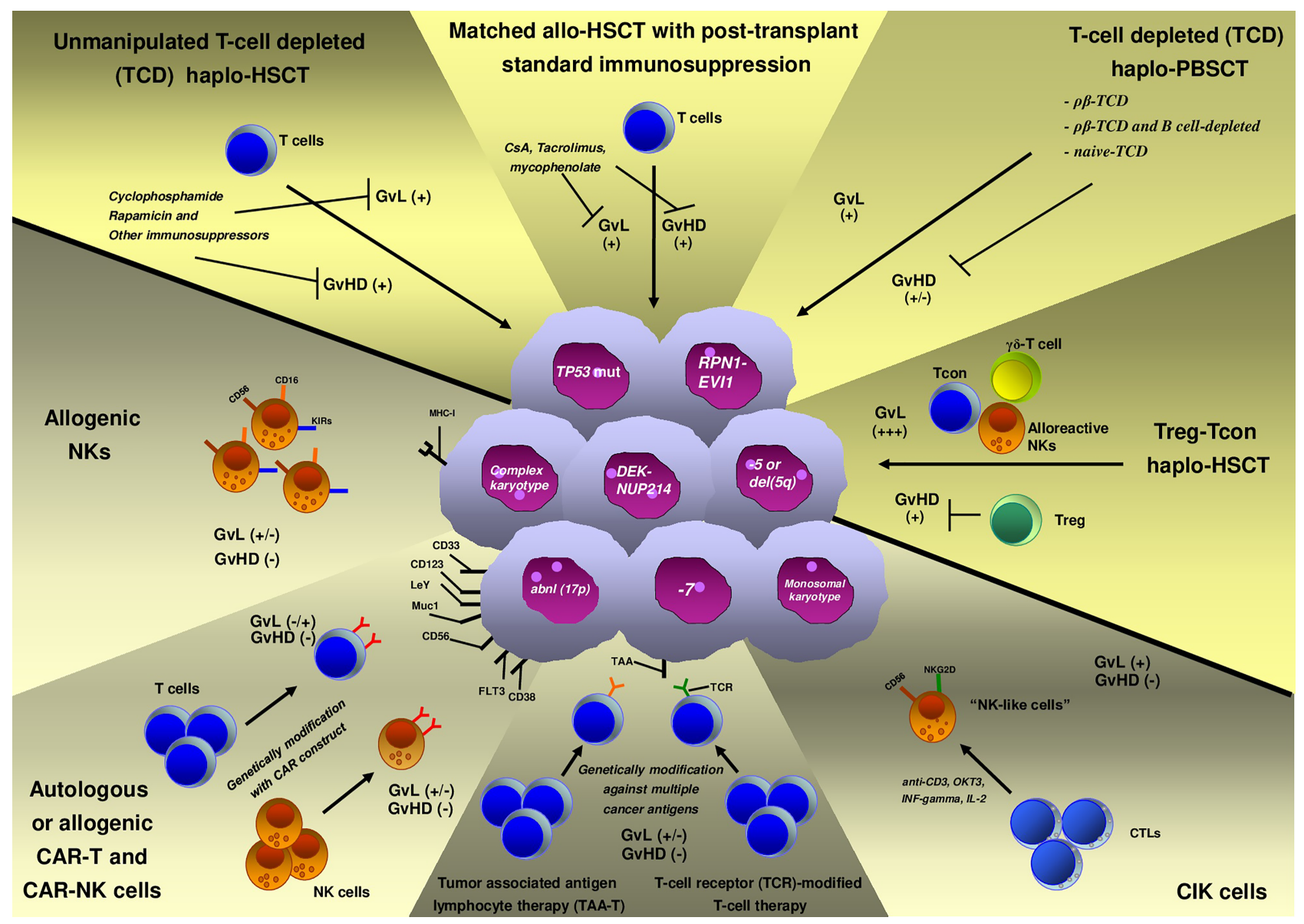

FIGURE 1 | Available immune cell-based therapies for high-risk acute myeloid leukemia (HR-AML). 
subsets of advanced leukemias (11-13). Beyond this, a plethora of other immune cell-based approaches are currently under investigation in blood tumors, including CAR-natural killer (NK) cells, cytokine-induced killer cells (CIK), and NK cells, as well as novel forms of CAR-T cells (dual CAR-T and multi-CART cells).

Allo-HSCT and especially HLA haploidentical allo-HSCT (haplo-HSCT) may serve as "discovery platforms" that can help to reveal the complex interplay between AML and the immune microenvironment and to set the base for pioneering studies of AML immune-targeting (Figure 1). However, conventional transplantation strategies have limited impact on HR-AML outcomes, as survival curves rarely exceed 30-35\% (14-16). In order to improve such outcomes, novel allo-HSCT strategies that exert more potent antileukemic activity need to be developed. Adoptive immunotherapy with conventional $\mathrm{T}$ cells (Tcons) and regulatory $\mathrm{T}$ cells (Tregs) is an innovative strategy that has been built to overcome disease chemoresistance and boost T-cell immunity, while preserving host tissues from graftversus-host disease (GvHD) damaging (17). In particular, Treg infusion in the absence of other forms of immune suppression allows for T cell-mediated killing of leukemic blasts. Thus, such approach resulted in prolonged and stable disease remission in the vast majority of HR-AML patients, as we have preliminarily observed in a proof-of-concept retrospective study (18).

In the present Perspective, we will review molecular mechanisms underlying HR-AML biology that drive disease relapse, as well as the potential impact of the newly developed approaches with target therapies on patients' outcomes. We will describe immune-based strategies against HR-AML in ongoing trials and discuss how refined transplantation approaches with adoptive immunotherapy might represent the "ultimate" therapeutic option for a definitive eradication of HR-AML.

\section{Molecular Genetics of HR-AML}

HR-AML includes many distinct biological entities, often characterized by an aggressive phenotype and intrinsic resistance to conventional treatments (2). HR-AML are not well defined in World Health Organization (WHO) classification, but this definition is widely used in clinical risk-adapted algorithms and also in the evaluation of the results from clinical trials. The major subgroup within this category consists of $A M L$ with highrisk cytogenetics, a subset of AML with different pathologic and clinical features that include the following:

- AML with complex karyotype (CK): its definition is not clear yet; however, it might be identified by the presence of $\geq 3$ chromosomal abnormalities not included in defined WHO categories, and not associated with favorable prognosis $(2,19,20)$

- AML with monosomal karyotype (MK): it is defined by the presence of at least two autosomal monosomies or one single autosomal monosomy in combination with at least one structural abnormality (21)

- AML bearing specific chromosomal aberrations: it is defined by the presence of specific genetic abnormalities such as inv(3) (q21.3q26.2) or $\mathrm{t}(3 ; 3)(\mathrm{q} 21.3 ; \mathrm{q} 26.2)$; GATA2,MECOM(EVI1); -5 or $\operatorname{del}(5 q) ;-7 ;-17 / \operatorname{abn}(17 p)(2)$

Specifically, CK AML have been recently proposed to be further divided into typical and atypical cases by the presence (or the absence, respectively) of $5 \mathrm{q}, 7 \mathrm{q}$, and/or $17 \mathrm{p}$ losses (22). Typical CK AML category bears TP53 mutations (almost absent within the atypical subgroup) more frequently and, thus, it is associated with poorer outcomes (compared to atypical cases). On the other hand, atypical CK AMLs are characterized by different mutational onco-prints and more frequently display mutations of RAS pathway-associated genes, NPM1 and/or FLT3 genes (22). Functional transcriptomic analyses of CK AML highlighted an elevated genomic instability with aberrant activation of DNA damage response and cell-cycle checkpoint pathways $(23,24)$. Although at very initial stages, genomic analyses of MK AML cases have consistently demonstrated that abnormalities involving chromosomes $5[-5$, or $\operatorname{del}(5 q)], 7(-7)$, and $17(-17 / a b n(17 p)$ are frequent in this setting, and strongly coupled to TP53 pathogenic mutations (25). However, other molecular pathways are implicated in MK AML pathogenesis and rely on a peculiar mutational signature targeting NOTCH1 (rarely reported in AML), BCOR/BCORL1, or RUNX1 genes (25). Interestingly, MK AML (as well as CK AML) are commonly associated with a catastrophic mutational phenomenon, namely, chromothripsis, that is promoted by clustered genomic rearrangements that result in multiple oncogenic hits and tumor-suppressors' inactivation (26). Eventually, such genomic events lead to the development of a highly proliferative disease. Specific aberrations involving chromosomes 3, 5, and 7 also clustered within HR-AML category. While chromosomes 5 and 7 aberrations are a common cytogenetic feature of trAML (4) and sAML that developed from previous myelodysplasia or myeloproliferative neoplasms (27), abnormalities involving chromosome $3[\operatorname{inv}(3)(\mathrm{q} 21.3 \mathrm{q} 26.2)$ or $\mathrm{t}$ $(3 ; 3)(\mathrm{q} 21.3 ; \mathrm{q} 26.2) ;$ GATA2,MECOM(EVI1)] could be related to a distinct (usually de novo) clinical-biological entity $(2,28)$. TP53 mutations and aberrant RAS pathway activity (NRAS, KRAS, PTPN11, NF1) are common features of trAML (27), as well as of EVI1-rearranged (EVI-r) AML $(28,29)$. Importantly, the latter is characterized by typical morphologic features (dysplastic megakaryocytes, multilineage dysplasia, and normal/elevated blood platelet counts) and driven by distinct molecular programs (like MECOM and IKZF1). EVI-r AML is associated with very poor overall survival (OS) $(28,29)$.

Furthermore, the 2017 European LeukemiaNet (ELN) adverse-risk category (2) also comprises specific WHO-defined genetic entities, which include wild-type NPM1 and FLT3ITD $^{\text {high }}$, mutated RUNX1, and mutated ASXL1. The molecular pathogenesis of each distinct genetic entity is very poorly understood, and future studies are needed to investigate such biological complexity.

\section{Ongoing Adoptive Cell Therapies}

The ability of leukemic blasts to evade immune surveillance has been recognized as a major mechanism of leukemia relapse after allo-HSCT (30). The novel use of immune therapeutics that aims 
to redirect the immune system against malignant blasts is now considered a new powerful tool to eradicate leukemia. Indeed, novel cellular immunotherapies with chimeric antigen receptor (CAR) T cells for B-lymphoproliferative disorders have recently achieved promising results (31) and generated great enthusiasm in the scientific community. As a matter of fact, a great number of studies are now emerging with the goal to provide similar effective treatments for various hematologic neoplasms. Cell therapy for AML is more complex than for lymphoid malignancies because myeloid leukemia-specific targets still need to be well identified. Many adoptive cell strategies are under investigation (Table 1) and are object of several clinical trials (45).

\section{Natural Killer (NK) Cells Adoptive Immunotherapies}

NK-cells are a subset of peripheral blood lymphocytes that are innately able to kill malignant cells through different mechanisms based on the balance between activatory and inhibitory signals. Interaction between major histocompatibility complex class I (MHC-I) molecules with killer immunoglobulin receptors (KIRs) on NK cells plays a major role in regulating NK cell function and activity. NK-cells kill leukemia cells when a mismatch between KIRs and their ligand on target cells is present (46). Such activity was demonstrated in T cell-depleted HLA-haploidentical transplant setting by the Perugia group and referred to as "NK cell alloreactivity" (47). The absence of any sort of pharmacologic immune suppression in TCD haplo-HSCT allowed for leukemia killing by alloreactive NK cells. On the other hand, the use of conventional immune suppressives to prevent GvHD in other transplant platforms may limit NK cell alloreactivity and its clinical effect (48). Further, NK cells may be dysfunctional and fail to kill AML blasts in case of abnormal phenotype, decreased degranulation level, and low INF-gamma and TNF-alfa production $(32,49,50)$. For many years, NK cell adoptive transfer has been investigated as a possible approach to treat HR-AML. Studies showed donor-derived allogeneic NK-cells achieved durable complete remission in $\sim 33 \%$ of HR-AML patients. Such studies proved infusion of a high number of NKcells to be safe and well-tolerated. Indeed, donor NK cells appear not to cause any GvHD $(33-35,51)$. Moreover, donor NK-cells are able to persist and expand in vivo after infusion. On the other hand, while promising, allogeneic NK cell adoptive transfer has still limited efficacy, with generally low overall response rate. To overcome such limitations and boost NK cell in vivo function, different protocols and schemes that aim to generate and activate NK-cells are under evaluation and further studies are needed to establish the most effective approach.

\section{Cytokine-Induced Killer (CIK) Cells}

CIK cells derived from cytotoxic T lymphocytes (CTL) that are in vitro activated by anti-CD3, OKT3, INF-gamma and subsequently expanded with IL-2. Other than T cell markers, they express surface protein similar to NK-cells, such as CD56, the inhibitory NK receptors, and the natural killer group 2 member D (NKG2D) receptor, one of the most important receptors involved in NK-mediated cancer cell killing (45). In clinical trials, CIK cells have been generated both from autologous and allogeneic lymphocytes and have been infused in combination or not with different strategies of allo-HSCT. Even if the results of early trials were disappointing (37), last studies are more encouraging $(36,38,39,52,53)$. CIK cell transfer resulted in stable complete remission in $\sim 60 \%$ of patients with AML. No significant infusion-related toxicities and a very low rate of acute GvHD were observed after CIK cell infusions. No studies focused on HR-AML, so that the efficacy in this setting still remains to be determined.

\section{Chimeric Antigen Receptor (CAR) T and NK Cells}

CAR-T cells are genetically engineered $\mathrm{T}$ cells to express a variable heavy and light chains $\left(\mathrm{V}_{\mathrm{HL}}\right)$ on cell surface with high specificity for malignant cell antigens (54). Despite the great enthusiasm that followed the CAR-T cell success in the treatment of acute B-lymphoblastic leukemia/lymphoma (B-ALL/LBL) and forms of B-cell lymphoma, generation of CAR-T cells against myeloid leukemic blasts is challenging because of the absence of leukemia-specific target antigens. In fact, AML antigens are often widely expressed by other hemopoietic cells or tissues. While in vitro studies and xenografts demonstrated the effectiveness of anti-CD33 and anti-CD123 CAR-T cells $(42,55)$, clinical efficacy on AML is still to be confirmed. CD33 is a transmembrane receptor expressed on $>90 \%$ of blasts, but unfortunately also on multilineage hematopoietic progenitors and myelomonocytic precursors. It was still validated as therapeutic target based on the efficacy of gemtuzumab ozogamicin, a drug-conjugated monoclonal antibody against CD33. Preliminary data of antiCD33 CAR-T cells are not encouraging (41). CD123 is a transmembrane subunit of the IL-3 receptor expressed on $100 \%$ of AML cells, and its expression is increased in FLT3mutated AML. In vitro ed in vivo (xenograft) preliminary data showed an increased cytokine release and decreased tumor burden using anti-CD123 CAR-T cells. FLT3 receptor is typically expressed on myeloid blasts, independent of FLT3 mutational status. Anti-FLT3 CAR-T cells showed in vitro ed in vivo promising antileukemic effect $(56,57)$. Moreover, these seem to be less toxic on normal hematopoiesis than the antiCD33 counterpart. Many other potential targets are now under evaluation. Lewis antigen (LeY) is overexpressed on myeloid blasts in comparison to normal tissues. A trial of autologous CAR-T cells targeting LeY showed a biological response ( $60 \%$ of patients), but relapse occurred within 2 years (40). An ongoing clinical trial (NCT03222674) evaluates the feasibility, safety, and efficacy of multi-CAR-T cell therapy that targets different AML surface antigens (Muc1/CLL1/CD33/CD38/CD56/CD123) in patients with relapsed/refractory AML. Another phase I study (NCT04156256) evaluates the safety and tolerability of CD123-CD33 dual CAR-T in patients with relapsed and/or refractory AMLs.

In alternative to CAR-T cells, CAR-NK cell therapy ideally combines the specific targeting provided by CARs with the NK cell ability to kill AML blasts in the absence of relevant systemic toxicity. Indeed, CAR-NK cells showed promising results with no important toxicity in lymphoma patients (58). Mouse preclinical models suggest that CD123 CAR-NK cells may be effective in AML (59). Clinical-grade CAR-NK cells can be 
TABLE 1 | | Selected published studies of immune cell-based strategies other than allogeneic transplantation for high-risk acute myeloid leukemia (HR-AML).

\begin{tabular}{lll}
\hline $\begin{array}{l}\text { Type of immune } \\
\text { cell-based therapy }\end{array}$ & Study design & AML patient cohort included in the study \\
& & $\begin{array}{l}\text { Outcomes } \\
\text { or others } \\
\text { identifier }\end{array}$
\end{tabular}

Natural killer (NK) Prospective trial of NK cells from haploidentical KIR-ligand-mismatched 17 adult acute myeloid leukemia (AML) patients adoptive

immunotherapy donors after fludarabine/cyclophosphamide chemotherapy, followed by (pts) in CR1

Phase 1 non-randomized open-label, dose-escalation trial of CNDO-109-Activated allogeneic NK Cells.

Phase 1 dose-escalation trial of membrane-bound interleukin 21

(mb-IL21) expanded donor NK cells infused before/after haploidentical allo-HSCT ${ }^{\mathrm{c}}$.

Phase 2 trial of donor NK lymphocyte infusion (NK-DLI) after

haploidentical allo-HSCT ${ }^{\mathrm{C}}$

Cytokine-induced Phase I study of allo-CIK cells in pts with blood tumors relapsed after killer (CIK) cells allo-HSCT ${ }^{\mathrm{c}}$.

Prospective enrolling study of allo-CIK in pts with high-risk leukemias

relapsed after cord-blood transplantation.

12 adult $A M L$ pts in $C R 1^{a}$ not eligible for allo-

$\mathrm{HSCT}^{\mathrm{C}}$ and at high risk for disease recurrence.

8 adult high-risk AML pts in morphologic remission.

$C R^{b}=9 / 16$ pts $(56 \%)$. (1 patient died due to infection).

Follow-up duration: 6-68 months.

8 pediatric and adult AML pts of a cohort of 16 pts Relapse rate $=4 / 8$ pts $(50 \%)$. with high-risk leukemia and highly malignant solid tumors.

4 adult $A M L$ pts.

NCT00799799 (32)

4 adult $A M L$ pts, including $2 / 4 R / R^{e} A M L$ and

2/4 in CR2

Retrospective study of allo-CIK administered after allo-HSCT ${ }^{\mathrm{C}}$ in pts with 5 adult AML pts $(n=5)$.

high-risk leukemias.

Phase I/II clinical trial of autologous CIK in pts with AML.

13 adult $A M L$ pts in $C R^{b}$

Chimeric antigen T Phase I study of autologous CAR anti-LeY T-cell therapy for AML.

(CART) cells

Phase 1/ll study of autologous CD33-directed CAR-T cells (CART-33) for 1 adult AML pt-

the treatment of $R / R^{e} A M L$.

Interventional open-label pilot study of RNA-redirected anti-CD123

autologous $T$-cell in patients with $R / R^{e} A M L$.

Single-center phase I dose-escalation study of a single infusion of

autologous NKG2D

Chimeric antigen Phase I study of CD33-CAR NK-92 cells in R/R $A M L$ pts.

natural killer

(CAR-NK) cells
4 adult $R / R^{e} A M L$ pts, including 3 pts treated in cytogenetic minimal residual disease, and $1 \mathrm{pt}$ in progressive disease.

5 adult AML pts.

7 adult AML pts, including 3 with CK, 3 with TP53 mutation, and 4 secondary $\mathrm{AML}$.

2 adult and 1 adolescent AML pts.
$\mathrm{CR}^{\mathrm{b}}=3 / 12$ pts $(25 \%)$.

Follow-up duration: 32.6-47.6 months.

$\mathrm{CR}^{\mathrm{b}}=7 / 8 \mathrm{pts}(88 \%)$

Follow-up duration: 7.9-15.9 months.

$\mathrm{CR}^{\mathrm{b}}$ rate and follow-up duration were not

specifically detailed for AML cohort.

Response in $0 / 4$ pts (0\%).

$\mathrm{PR}^{\mathrm{g}}$ in $1 / 4$ pts $(25 \%)$.

Follow-up duration: $~ 4$ months.

$\mathrm{CMR}^{\mathrm{h}}=4 / 5$ pts $(80 \%)$.

$\mathrm{CR}^{\mathrm{b}}=6 / 13(46 \%)$.

Follow-up duration: 38-50 months.

$C R^{b}=1 / 4(25 \%)$.

Follow-up duration: 23 months.

Partial remission $(P R)=1 / 1$.

Follow-up duration: 3 months.

$\mathrm{CR}^{\mathrm{b}}=0 / 5$.

All patient progressed at day 28

No objective response.

NCT01520558 (33)

NCT01904136 (34)

NCT01386619 (35)

$\mathrm{N} / \mathrm{A}^{\dagger}(36)$

$\mathrm{N} / \mathrm{A}^{\dagger}(37)$

$N / A^{f}(38)$

NCT00394381 (39)

CTX 08-0002 (40)

(Australia)

NCT01864902 (41)

NCT02623582 (42)

NCT02203825 (43)

2/3 pts achieved $C R^{b}$.

Relapse occurred in the 2 pts, 4 months

after CAR-NK cells infusion
Follow-up duration: 6.9-16 months.

${ }^{a} C R 1$, first complete remission; ${ }^{b} \mathrm{CR}$, complete remission; ${ }^{\mathrm{C}} \mathrm{All}$ - $\mathrm{HSCT}$, allogeneic hematopoietic stem cell transplantation; ${ }^{d} \mathrm{CR} 2$, second complete remission; ${ }^{e} R / R$, relapsed/refractory; ${ }^{f} \mathrm{~N} / \mathrm{A}$, not available; ${ }^{g} P R$, partial response; ${ }^{h} \mathrm{CMR}$, complete molecular remission; 'CK, complex karyotype. 
manufactured from multiple sources (e.g., peripheral blood mononuclear cells, umbilical cord blood, hematopoietic progenitors, induced pluripotent stem cells), including the recently introduced CAR NK-92 cells, which consist of a modified CAR-engineered form of the NK-92 cell line. Such cell line represents an easily manageable and cost-effective tool for large-scale production of CAR-NK cells. Conversely, few drawbacks should be taken into account when using such strategy for CAR-NK cell manufacturing: i) failure of an in vivo expansion, due to lethal irradiation before infusion; ii) lack of NK-cell activating molecules (CD16 and NKp44); iii) potential in vivo tumorigenicity (60). The first-in-human clinical trial using CD33 CAR-NK cells derived from engineered NK-92 cells on three relapse/refractory extramedullary AML patients had no encouraging results ( $1 / 3$ reached a transitory complete remission of 4 months) (44). Other trials with CD33 CAR-NK cells are under investigation (NCT02892695, NCT02944162). Such studies will help to clarify whether combinatorial strategies can provide antileukemic activity in the absence of relevant toxicity. While there was no specific focus on HR-AML in these preliminary studies and no clear studies showed HRAML to be particularly sensitive to immune killing, the development of an effective anti-AML CAR-T or CAR-NK cell approach might provide a potent tool for reducing relapse in this high-risk disease.

\section{Other Adoptive Cell Therapies in the Near Future}

$\mathrm{T}$ cells can be engineered to target different tumor-associated antigens that are frequently expressed in advanced AML blasts and other hematological neoplasms. Preliminary results of such tumor-associated antigen lymphocyte therapy (TAA-T) for different relapsed hematologic malignancies after allo-HSCT (11 patient, Hodgkin's lymphoma $n=2, B-A L L ~ n=3$, AML $n=5$, and 1 HR-AML post $2^{\text {nd }}$ allo-HSCT) showed that $80 \%$ of patients (4/5) with AML achieved a stable complete remission (61). This study also suggested TAA-T to be safe and tolerable (only one patient showed a liver GvHD; no cytokine release syndrome or neurotoxicity was observed). These preliminary promising data suggest that TAA-T therapy may be a feasible option for preemptive treatment of relapse after allo-HSCT for HR-AML, but further clinical studies are needed to ascertain its feasibility and efficacy in this setting. T-cell receptor (TCR)-modified T-cell therapy is a novel emerging strategy using the anti-tumor effect of genetically modifying T cells through the transduction of TCR genes against several cancer antigens $(62,63)$. The impact of this therapy against specific leukemic antigens is still under investigation. This therapy seems also very safe (64). The in vitro and in vivo preliminary studies on B-malignancies are very promising (65).

\section{Allo-HSCT Strategies: Is There Room for the Cure of High-Risk Acute Myeloid Leukemias?}

Allo-HSCT is the only treatment modality that can provide a long-term survival benefit for HR-AML (Table 2), although current conventional transplantation strategies have scarce effect on HR-AML outcomes, with a maximum 2-year OS of $30-35 \%$ and a higher relapse rate when compared to other cytogenetic risk categories (14-16).

\section{HLA-Matched Allo-HSCT}

A multicenter study of HLA-matched allo-HSCT that employed various immunosuppressive strategies for GvHD prophylaxis (cyclosporine A, tacrolimus, and T-cell depletion) compared a total of 584 patients carrying HR-AML in first complete remission (CR1) from 151 transplantation centers. It showed a median 3-year OS of 45\% (range 38-52\%), 37\% (range 31-44\%), and $31 \%$ (range $22-41 \%$ ) in patients undergoing matched sibling donor (MSD), HLA-well-matched and partially-matched unrelated donor (MUD) transplantation, respectively. Myeloablative or reduced-intensity conditioning (RIC) regimens were used. Cumulative incidence (CI) of relapse at 3 years was $37 \%$ for MSD, $40 \%$ for well-MUD, and $24 \%$ for partially-MUD, while 3-year relapse-free survival (RFS) was 42 , 34 , and $29 \%$, respectively. No significant differences in relapse were observed among the various cytogenetic subsets (66). Another retrospective multicenter study that involved more than 500 transplantation centers reported outcomes of 1,342 patients with CK-AML. Increased risk of relapse correlated with age, secondary AML, active disease at transplant, and the presence of deletion/monosomy 5 . High tumor burden before transplant negatively impacted on post-transplantation outcomes. Indeed, 2-year CI of relapse for patients in CR and with active disease at transplantation was 47 and 64\%, respectively. A very short OS at 2 years post-transplantation was observed in a subgroup of patients carrying deletion or monosomy 7 and deletion or monosomy 5 (29 and 20\% respectively $v s 42 \%$ in control groups without 7 and 5 deletion/ monosomy). No significant survival benefit was observed between fully myeloablative conditioning and RIC regimen for patients with CK AML (34 and 28\%). RFS rate was $39.9,33$, and $18.3 \%$ for patients ages $<40,40$ to 60 , and $>60$ years, respectively (14). Such studies demonstrate that the high relapse incidence after transplant in HR-AML patients is the major limitation of the procedure. Such outcomes urge the development of novel transplantation approaches.

\section{Haplo-HSCT}

The recent advancements in T-cell manipulation and in GvHD prophylaxis make haplo-HSCT a valuable transplantation strategy to overcome intrinsic chemotherapy resistance of high-risk leukemias. Haplo-HSCT procedures can be mainly divided in two major categories: T-cell depleted (TCD) peripheral-blood stem cells (PBSCs) haplo-HSCT and unmanipulated haplo-HSCT.

Unmanipulated haplo-HSCT relies on pharmacologic GvHD prophylaxis, and it is now adopted worldwide. The use of G-CSF-primed grafts $(67,77)$, post-transplant high-dose cyclophosphamide (PT-Cy) in combination with other immunosuppressive drugs $(78,79)$, and post-transplant rapamycin (80), are different approaches that have been tested in this setting. While such strategies help to keep non-relapse mortality (NRM) acceptable, disease relapse remains a major 
TABLE 2 | Selected published strategies of allogeneic hematopoietic stem cell transplantation (allo-HSCT) for high-risk acute myeloid leukemia (HR-AML)

\begin{tabular}{|c|c|c|c|c|c|c|}
\hline $\begin{array}{l}\text { Allo-HSCT } \\
\text { strategy }\end{array}$ & Study design & $\begin{array}{l}\text { AML patient cohort } \\
\text { in the study }\end{array}$ & $\begin{array}{l}\text { Conditioning } \\
\text { regimen }\end{array}$ & $\begin{array}{l}\text { Graft-versus-Host Disease } \\
\text { (GvHD) prophylaxis }\end{array}$ & Outcomes & Ref. \\
\hline \multirow[t]{2}{*}{$\begin{array}{l}\text { HLA-matched } \\
\text { allo-HSCT }\end{array}$} & $\begin{array}{l}\text { Retrospective multicenter study of } \mathrm{URD}^{\mathrm{a}} \text { and } \\
\mathrm{MSD}^{\mathrm{b}} \text { allo-HSCT in patients (pts) with high-risk } \\
\text { acute myeloid leukemia (HR-AML) in } C R 1^{\mathrm{c}} \text {. }\end{array}$ & $\begin{array}{l}584 \text { adult HR-AML pts: } \\
- \text { CK }^{\mathrm{d}}: 32 \% \\
- \text { - } 7 / \text { del }(7 q): 25 \% \\
\text { - Others: } 43 \%\end{array}$ & $\begin{array}{l}\text { MACe: } \\
\text { - MSD }{ }^{\mathrm{b}}: \mathrm{n}=183 \\
\text { - URD }{ }^{\mathrm{a}}: \mathrm{n}=252 \\
\text { RIC } \mathrm{C}^{\mathrm{f}} \\
\text { - MSD } \\
\text { - URD }: \mathrm{n}=252 \\
\end{array}$ & $\begin{array}{l}\text { ATG': } \\
\text { - MSD }: n=18 \\
\text { - URD }: n=96 \\
\text { CsA }^{\mathrm{h}}: \\
\text { - MSD }: n=155 \\
\text { - URD }: n=137 \\
\text { Tacrolimus: } \\
\text { - MSD }: n=40 \\
\text { - URD }: n=191 \\
\text { T-cell depletion: } \\
\text { - MSD }: n=20 \\
\text { - URD }: n=29 \\
\text { Others/missing: } \\
\text { - MSD } n=11 \\
\text { - URD }: n=\end{array}$ & $\begin{array}{l}\text { 3-year OS }: \\
\text { - } \text { MSD }^{\mathrm{b}}=45 \% \\
\text { - HLA-well-matched } \mathrm{URD}^{\mathrm{a}}=37 \% \\
\text { - Partially-matched URD }=31 \% \\
\text { Median follow-up: } \\
\text { - } \text { MSD }^{\mathrm{b}}: 61 \text { months } \\
\text { - URD }: 35 \text { months } \\
\text { 3-year TRM: } \\
\text { - } \text { MSD }^{\mathrm{b}}=21 \% \\
\text { - HLA-well-matched } \mathrm{URD}^{\mathrm{a}}=26 \% \\
\text { - Partially-matched } \mathrm{URD}^{\mathrm{a}}=47 \%\end{array}$ & (66) \\
\hline & $\begin{array}{l}\text { Retrospective multicenter study of } \mathrm{MSD}^{\mathrm{b}}, \mathrm{MUD}^{\mathrm{p}} \text {, } \\
\text { and MMUD allo-HSCT in } \mathrm{CK}^{\mathrm{d}} \mathrm{AML} \text { pts. }\end{array}$ & $\begin{array}{l}1,342 \text { adult } C^{d} \text { AML } \\
\text { pts: } \\
-357 \text { with }-7 / \text { del }(7 q) \\
-259 \text { with }-5 / \text { del( }(5 q)\end{array}$ & $\begin{array}{l}\text { MAC }^{e}: n=739 \\
\text { RIC }^{f}: n=603\end{array}$ & T-cell depletion: $n=665$ & $\begin{array}{l}2 \text {-year } \mathrm{OS}^{\mathrm{m}}=36.8 \% \\
2 \text {-year } \mathrm{NRM}^{\circ}=17.6 \%\end{array}$ & (14) \\
\hline \multirow[t]{6}{*}{$\begin{array}{l}\text { HLA-haploidentical allo-HSCT } \\
\text { (Haplo-HSCT) }\end{array}$} & $\begin{array}{l}\text { Prospective multicenter trial of G-CSF-primed } \\
\text { grafts for haploidentical allo-HSCT in pts with } \\
\text { blood neoplasms. }\end{array}$ & $\begin{array}{l}45 \text { adult AML pts: } \\
-34 \text { standard-risk AML } \\
-11 \text { HR-AML } \\
\text { In HR-AML group: } \\
-2 \text { pts in } \text { CR3 }^{n} \\
-9 \text { pts with active } \\
\text { disease }\end{array}$ & $\begin{array}{l}\text { MAC }: n=64 \\
\text { RIC }^{f}: n=16\end{array}$ & $\begin{array}{l}\text { ATG }^{9} \\
\text { CsA }^{\mathrm{h}} \\
\text { Methotrexate } \\
\text { Mycophenolate } \\
\text { Basiliximab }\end{array}$ & 18-month LFS ${ }^{x}=44 \%$ & (67) \\
\hline & $\begin{array}{l}\text { Retrospective multicenter study of } \\
\text { unmanipulated haploidentical allo-HSCT } \\
\text { in patients with AML. }\end{array}$ & $\begin{array}{l}\text { Within the entire AML } \\
\text { cohort: } \\
\text { - } 99 \text { pts in CR' } \\
\text { - } 51 \text { pts with active } \\
\text { disease } 150 \text { adult AML } \\
\text { pts: } \\
\text { - } 95 \text { HR-AML }\end{array}$ & $\mathrm{MAC}^{\mathrm{e}}$ & $\begin{array}{l}\text { CsA }^{\mathrm{h}} \\
\text { Mycophenolate }\end{array}$ & 4 -year OS ${ }^{h}=57 \%$ & (68) \\
\hline & $\begin{array}{l}\text { Retrospective single-center analysis of } \mathrm{MSD}^{\mathrm{b}} \text { vs } \\
\mathrm{URD}^{\mathrm{a}} \text { vs HRD } \mathrm{H} \text { allo-HSCT for pts }>60 \text { years with } \\
\text { AML. }\end{array}$ & $\begin{array}{l}94 \text { adult } A M L \text { pts: } \\
\text { - } 28 \text { HR-AML }\end{array}$ & $\begin{array}{l}\text { In HRD }{ }^{r} \text { allo-HSCT: } \\
M A C^{e}: n=0\end{array}$ & $\begin{array}{l}\text { In HRD }{ }^{r} \text { allo-HSCT: } \\
\text { Post-transplant } \\
\text { cyclophosphamide }\end{array}$ & $\begin{array}{l}4 \text {-year } \operatorname{TRM}^{i}=20 \% \\
2 \text {-year } \mathrm{OS}^{h}=55 \%\end{array}$ & (69) \\
\hline & & $\begin{array}{l}\text { Within the entire AML } \\
\text { cohort: }\end{array}$ & Non-MAC: $\mathrm{n}=9$ & $\mathrm{CsA}^{\mathrm{h}}$ & 2 -year $\operatorname{TRM}^{d}=24 \%$ & \\
\hline & & $\begin{array}{l}-80 \text { pts in } C^{\prime} \\
-14 \text { with active } \\
\text { disease }\end{array}$ & $R I C^{f}: n=24$ & Mycophenolate & 2 -year GRFS ${ }^{e}=32 \%$ & \\
\hline & $\begin{array}{l}\text { Prospective trial of } \mathrm{TCR}^{\mathrm{s}} \mathrm{HRD}^{r} \text { allo-HSCT in pts } \\
\text { with blood neoplasms, compared with a } \\
\text { retrospective cohort of pts treated with } \mathrm{TCD}^{\mathrm{t}} \\
\text { haplo-HSCT. }\end{array}$ & $\begin{array}{l}65 \text { pts: } \\
-42 \text { AML/MDS }\end{array}$ & $\begin{array}{l}T_{C R^{s}} \text { group }(n=32): \\
-M A C^{*}: n=26\end{array}$ & $\begin{array}{l}\text { In TCR: } \\
\text { Post-transplant } \\
\text { cyclophosphamide, } \\
\text { Tacrolimus, }\end{array}$ & $\begin{array}{l}1 \text {-year OS } \\
- \text { TCR }^{\mathrm{s}}=64 \%\end{array}$ & (70) \\
\hline
\end{tabular}




\begin{tabular}{|c|c|c|c|c|c|c|}
\hline $\begin{array}{l}\text { Allo-HSCT } \\
\text { strategy }\end{array}$ & Study design & $\begin{array}{l}\text { AML patient cohort } \\
\text { in the study }\end{array}$ & $\begin{array}{l}\text { Conditioning } \\
\text { regimen }\end{array}$ & $\begin{array}{l}\text { Graft-versus-Host Disease } \\
\text { (GvHD) prophylaxis }\end{array}$ & Outcomes & Ref. \\
\hline & & & $\begin{array}{l}- \text { RIC }^{\mathrm{f}}: \mathrm{n}=6 \\
\text { TCD }^{\mathrm{t}} \text { group }(n=33): \\
\text { - } \text { MAC }^{\mathrm{e}}\end{array}$ & $\begin{array}{l}\text { Mycophenolate } \\
\text { In TCD: } \\
\text { ATG }^{9}\end{array}$ & $\begin{array}{l}-\operatorname{TCD}^{\mathrm{t}}=30 \% \\
\text { 1-year } \mathrm{TRM}^{\mathrm{i}}: \\
-\mathrm{TCR}^{\mathrm{s}}=16 \% \\
-\mathrm{TCD}^{\mathrm{t}}=42 \%\end{array}$ & \\
\hline & $\begin{array}{l}\text { Prospective trial of } \alpha / \beta \mathrm{TCD}^{\mathrm{t}} \mathrm{HRD}^{\mathrm{r}} \text { allo-HSCT } \\
\text { without ATG in children with chemorefractory } \\
\text { AML. }\end{array}$ & $\begin{array}{l}22 \mathrm{AML}: \\
-9 \mathrm{HR}-\mathrm{AML} \\
-10 \text { primary refractory } \\
-12 \mathrm{R} / \mathrm{R}^{\mathrm{u}} \mathrm{AML} \text { with } \\
\text { active disease }\end{array}$ & $\mathrm{MAC}^{\mathrm{e}}$ & $\begin{array}{l}\text { Bortezomib and tocilizumab } \\
+/- \text { abatacept }\end{array}$ & $\begin{array}{l}\text { 2-year } \mathrm{OS}^{\mathrm{m}}=53 \% \\
\text { 2-year } \mathrm{EFS}^{v} \text { for } \mathrm{HR}-\mathrm{AML}=44 \% \\
\mathrm{TRM}^{\prime}=9 \%\end{array}$ & (71) \\
\hline & \multirow[t]{2}{*}{$\begin{array}{l}\text { Retrospective analysis in children with } H R-A M L \text { in } \\
C R^{\prime} \text { receiving } \alpha / \beta T^{t} C D^{t} H R D^{r} \text { allo-HSCT or } M U D^{p} \text {. }\end{array}$} & 73 HR-AML: & \multirow[t]{2}{*}{ MAC $^{e}$} & $\begin{array}{l}36 \text { pts } \mathrm{ATG}^{9} \text {, tacrolimus and } \\
\text { methotrexate }\end{array}$ & 3-year OS ${ }^{m}: 74 \%$ & \multirow[t]{2}{*}{ (72) } \\
\hline & & $\begin{array}{l}-59 \text { pts in CR1 } \\
-14 \text { pts } \geq \mathrm{CR} 2^{\mathrm{w}}\end{array}$ & & $\begin{array}{l}47 \text { pts } \text { ATG }^{9} \text {, Bortezomib and } \\
\text { rituximab }\end{array}$ & 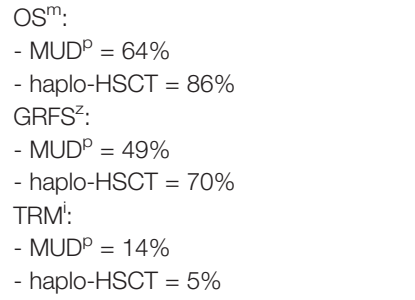 & \\
\hline & \multirow[t]{2}{*}{$\begin{array}{l}\text { Prospective trial of } \alpha / \beta \text { TCD }^{t} \text { and } B \\
\text { cell-depleted HRD }{ }^{r} \text { allo-HSCT in children with AL. }\end{array}$} & $\begin{array}{l}80 \text { AL: } \\
-24 \mathrm{CR}^{i}\left(\mathrm{CR} 1^{\mathrm{c}}=16\right. \\
\left.\mathrm{CR} 2^{\mathrm{w}}=8\right)\end{array}$ & \multirow[t]{2}{*}{$\mathrm{MAC}^{\mathrm{e}}$} & \multirow[t]{2}{*}{ ATG $^{9}$} & $\begin{array}{l}\text { For entire cohort: } \\
5 \text {-year } \mathrm{OS}^{\mathrm{m}}=72 \%\end{array}$ & \multirow[t]{2}{*}{ (73) } \\
\hline & & - 4 HR-AML & & & $\begin{array}{l}5 \text {-year } \mathrm{CRFS}^{\mathrm{y}}=71 \% \\
\text { 5-year TRM }=5 \% \\
\text { For AML sub-cohort: } \\
5 \text {-year } \mathrm{LFS}^{\times}=68 \%\end{array}$ & \\
\hline & $\begin{array}{l}\text { Retrospective multicenter comparative analysis of } \\
\text { URD }{ }^{a} \text { - or } \alpha / \beta T^{\prime} C D^{t} H R D^{r} \text { allo-HSCT in children } \\
\text { with } A L \text {. }\end{array}$ & $\begin{array}{l}\text { 342 AL: } \\
\text { - MUDD: } 127 \\
\text { - MMUD }: 118 \\
\text { - HRD': } 98 \\
105 \text { CR' AML: }^{\mathrm{q}} \text { - } \\
\text { - MUD': } 43 \\
\text { - MMUD': } 32 \\
\text { - haplo-HSCT: } 30\end{array}$ & $\mathrm{MAC}^{\mathrm{e}}$ & $\begin{array}{l}\text { In } \mathrm{HRD}^{r} \text { allo-HSCT: } \\
\alpha / \beta^{+} \text {and } \mathrm{CD} 19^{+} \text {negative } \\
\text { selection }+\mathrm{ATG}^{\mathrm{g}}\end{array}$ & $\begin{array}{l}\text { For } \alpha / \beta \text { TCD }^{t} \text { haplo-HSCT AL cohort: } \\
5 \text {-year probability of OS }{ }^{m}=68 \% \\
5 \text {-year } \text { LFS }^{x}=62 \% \\
5 \text {-year } \text { CRFS }^{y}=59 \% \\
\text { TRM' }^{\prime}=9 \% \\
\text { Cumulative incidence of relapse for } \\
\text { AML sub-cohort }=21 \%\end{array}$ & (74) \\
\hline & $\begin{array}{l}\text { Prospective single-arm clinical trial of naïve } T_{C D}{ }^{t} \\
\text { peripheral blood stem cells grafts for adult pts } \\
\text { with high-risk leukemia. }\end{array}$ & $\begin{array}{l}35 \text { Adult high-risk } \\
\text { leukemia: } \\
\text { - } 10 \mathrm{AML}\end{array}$ & $\mathrm{MAC}^{\mathrm{e}}$ & Tacrolimus & 2 -year $\mathrm{OS}^{m}=78 \%$ & (75) \\
\hline & $\begin{array}{l}\text { Prospective single-center trial of adult AML pts } \\
\text { undergoing HRD } \text { HRllo-HSCT combined with }^{r} \\
\text { regulatory and conventional T cells adoptive } \\
\text { immunotherapy }\end{array}$ & $\begin{array}{l}50 \text { adult AML pts: } \\
-20 \mathrm{HR}^{-A M L} \\
-42 \mathrm{CR}^{\mathrm{i}} \\
-8 \text { with active disease }\end{array}$ & Age-adapted MAC & None & $\begin{array}{l}\text { 29-month } \mathrm{OS}^{\mathrm{m}}=77 \% \\
\text { CRFS }^{\mathrm{y}}=75 \% \\
\text { CRFS }^{\mathrm{y}} \text { (for HR-AML) }=72 \% \\
\text { TRM' }^{\prime}=21 \% \\
\text { Cumulative Incidence of relapse: } 4 \%\end{array}$ & (76) \\
\hline
\end{tabular}

${ }^{a} U R D$, unrelated donor; ${ }^{b} \mathrm{MSD}$, matched sibling donor; ${ }^{\mathrm{C}} \mathrm{CR} 1$, first complete remission; ${ }^{d} \mathrm{CK}$, complex karyotype; ${ }^{\mathrm{M}} \mathrm{MAC}$, Myeloablative conditioning regimen; ${ }^{\mathrm{f}} \mathrm{RIC}, \mathrm{Reduced-intensity}$ conditioning regimen; ${ }^{g} \mathrm{ATG}$, anti-thymocyte

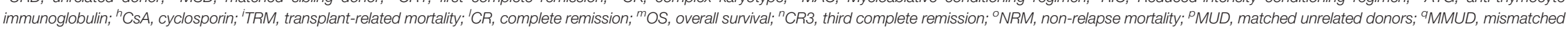
unrelated donors; ${ }^{r} H R D$, haploidentical related donor; ${ }^{\top} T C R$, $T$-cell replete; ${ }^{t} T C D, T$-cell deplete; ${ }^{u} R / R$, relapsed/refractory; ${ }^{v} E F S$, event-free survival; ${ }^{2} G R F S$, GvHD-free, relapse-free survival; ${ }^{w} C R 2$, second complete remission; ${ }^{\top} L F S$, leukemiafree survival; ${ }^{y} C R F S$, chronic GvHD-free, relapse-free survival. 
concern, especially when non-myeloablative conditioning regimens are used (81). A study of unmanipulated G-CSFprimed haplo-HSCT showed a 1-year CI of NRM of $36 \%$ and a CI of relapse of $21 \%$ at 1 year and $28 \%$ at 5 years respectively, with a 3 -year probability of OS and RFS in 44 and 30\%, respectively, in high-risk patients ( $>$ second CR or active disease) with hematologic malignancies (including HR-AML) (67). Haplo-HSCT with PT-Cy is now the most widely adopted haplo-HSCT platform, thanks to acceptable rates of acute and chronic GvHD, low NRM, no need of graft manipulation and contained costs. On the other hand, relapse rates are still disappointing in HR-AML patients. In fact, subanalyses showing outcomes of patients with adverse genetic risk AML reported relapse rates up to $50 \%$ (14). Because of such limitation and with the goal of reducing leukemia relapse, high-intensity myeloablative conditioning regimens have been employed. Chiusolo $P$ et al. (68) and Devillier $R$ et al. (69) showed a CI of AML relapse of $24 \%$ at 4 years and $25 \%$ at 2 years, respectively. Further studies will be needed to evaluate if such strategies are effective in subsets of HR-AML patients.

\section{T-Cell Depleted Haplo-HSCT}

In the last 20 years, several strategies of ex vivo T-cell depletion (TCD) have been tested to improve outcomes of acute leukemia patients who underwent haplo-HSCT. While traditional TCD procedure based on positive selection of CD34+ cells was associated with delayed immune reconstitution and increased risk of NRM $(70,82)$, more recent strategies are directed towards the preservation of immune subsets that improve post-transplant immune recovery for more effective anti-infective and antileukemic activities (82). Among these, $\alpha \beta$ T-cell-depleted haplo-HSCT appears to be an effective platform for the treatment of HR-AML. In $\alpha \beta$ T-cell-depleted haplo-HSCT the graft is manipulated to eliminate T cells that express $\alpha \beta \mathrm{T}$ cell receptor and which are demonstrated to be the main $\mathrm{T}$ cell population responsible for alloreactions that cause GvHD. In the studies by Shelikhova L et al. (71) and Maschan $M$ et al. (72), children with primary refractory or relapsed AML who underwent $\alpha \beta$ T-celldepleted haplo-HSCT reached hematologic complete remission, despite 9/22 of them carried adverse-risk cytogenetics. However, the relapse rate and OS at 2 years after allo-HSCT were 42 and $52 \%$, respectively. In different studies by Locatelli F et al. (73) and Bertaina A et al. (74), $\alpha \beta$ T-cell and B-cell-depleted haplo-HSCT proved to be a safe and suitable approach in high-risk acute leukemias (HR-AL) in children. Indeed, it achieved a 5-year probability of chronic GvHD-free/relapse-free (GRFS) survival of $71 \%$ in HR-AL patients (73). A novel TCD haplo-HCT platform employs grafts that have been selectively depleted of naive $T$-cells. Indeed, depletion of naïve $T$ cells $\left(T_{N}\right)$ from PBSC preserves hematopoietic engraftment and allows for the transfer of donor-derived memory $\mathrm{T}$ cells, that can confer immunity against pathogens with low risk of GvHD (75). This approach has demonstrated to improve outcomes of HR-AL patients (the 2 -year relapse rate was $21 \%$ and the 2 -year RFS was $70 \%$ ) in a single-arm trial (75). Thus, such approaches are promising, but relapse rates still reduce outcomes of HR-AL patients.

\section{Haploidentical HSCT Combined With Regulatory and Conventional T-Cells Adoptive Immunotherapy}

We have recently demonstrated that haplo-HSCT combined with regulatory and conventional $\mathrm{T}$-cells adoptive immunotherapy (Treg-Tcon haplo-HSCT) is able to overcome disease-intrinsic chemoresistance $(18,76)$. We enrolled 50 AML patients in the study; $40 \%$ of them (20/50) had HR-AML. An "age-adapted" myeloablative conditioning based on total body irradiation (TBI) for patients up to the age of 50 years and total marrow/total lymphoid irradiation (TMLI) for patients aged 5165 years was followed by thiotepa, fludarabine, and cyclophosphamide. No pharmacological GvHD prophylaxis was given. Two millions/kg donor regulatory $\mathrm{T}$ cells were given at day -4 to allow for their alloantigen-specific in vivo expansion. One million $/ \mathrm{kg}$ conventional $\mathrm{T}$ cells were given at day -1 and were followed by the infusion of a "megadose" of purified CD34+ hematopoietic progenitor cells at day 0 . Fifteen/50 patients developed grade $\geq 2$ acute GvHD (aGvHD). Moderate/severe cGvHD occurred in only one patient. Only two patients relapsed (4\%). Consequently, at a median follow-up of 29 months, the probability of moderate/severe cGvHD/relapsefree survival was $75 \%(18,76)$. TMLI allowed to safely extend the powerful effect of a myeloablative conditioning to older ( $>60$ years old) patients. Further, when looking at the different genetic signatures of the enrolled AML patients, we found that HR-AML did not have a higher risk of relapse in comparison to more favorable subgroups. Indeed 17 of the $20 \mathrm{HR}$-AML patients are alive and leukemia-free despite many of them had detectable disease at transplant. Such results demonstrate HR-AML to be sensible to immune-mediated killing. Indeed, the absence of pharmacologic immune suppression in Treg/Tcon haplo-HSCT could have favored a potent GvL effect that was exerted across all the AML subsets and that was not limited by disease burden and previous refractoriness to chemotherapeutic agents. ELN AML genetic risk stratification is considered to retain outcome prediction after allo-HSCT (83). However, our study showed that effect was lost after Treg/Tcon haplo-HSCT in a single series of 50 AML patients. While larger multicentric studies are needed to support such conclusion, the potent GvL activity of Treg/Tcon haplo-HSCT appears to be an effective tool for the treatment of such unfavorable AML.

\section{DISCUSSION}

HR-AMLs are usually characterized by a very poor response to conventional treatments and to conventional allo-HSCT. Indeed, relapse rates are high (often above 50\%) and result in very low survival (often below 10-20\%). Thus, novel effective strategies are needed. Recent studies on new adoptive cell strategies (CART cells, CAR-NK cells, CIKs, activated NK cells) bring new hopes for the treatment of such unfavorable diseases. Indeed, immunecell-based therapies may represent a powerful tool to successfully treat chemoresistant HR-AML. NK cell adoptive immunotherapies are a promising therapeutic, but their efficacy is still limited and fine-tuning of the approach is still 
required for larger clinical use (32-35). The more recently introduced CAR-T- and CAR-NK-cell-based treatments demonstrated high potency in pilot studies and hold great promise (40-44). The growing body of clinical studies and broader use of these agents in different settings and against novel targets will provide key information on their ability to eradicate HR-AML. Furthermore, we have recently demonstrated that Treg-Tcon haplo-HSCT is able to overcome HR-AML intrinsic chemoresistance, prevent relapse, and improve survival $(18,76)$. This study strongly suggests that HR-AMLs are sensitive to antileukemic immunity. The introduction of new immune therapeutics that strengthen immune activity against leukemia and the development of transplantation approaches that favor unopposed GvL might help to develop powerful tools for an effective treatment of HR-AML.

\section{DATA AVAILABILITY STATEMENT}

The original contributions presented in the study are included in the article/supplementary material. Further inquiries can be directed to the corresponding author.

\section{REFERENCES}

1. Schiller GJ. High-Risk Acute Myelogenous Leukemia: Treatment Today and Tomorrow. Hematol Am Soc Hematol Educ Prog (2013) 2013:201-8. doi: 10.1182/asheducation-2013.1.201

2. Dohner H, Estey E, Grimwade D, Amadori S, Appelbaum FR, Büchner T, et al. Diagnosis and Management of AML in Adults: ELN Recommendations From an International Expert Panel. Blood (2017) 129(4):424-47. doi: 10.1182/blood-2016-08-733196

3. Arber DA, Orazi A, Hasserjian R, Thiele J, Borowitz MJ, Le Beau MM, et al. The 2016 Revision to the World Health Organization Classification of Myeloid Neoplasms and Acute Leukemia. Blood (2016) 127(20):2391-405. doi: 10.1182/blood-2016-03-643544

4. Boddu P, Kantarjian HM, Garcia-Manero G, Ravandi F, Verstovsek S, Jabbour E, et al. Treated Secondary Acute Myeloid Leukemia: A Distinct High-Risk Subset of AML With Adverse Prognosis. Blood Adv (2017) 1 (17):1312-23. doi: 10.1182/bloodadvances.2017008227

5. Lancet JE, Uy GL, Cortes JE, Newell LF, Lin TL, Ritchie EK, et al. CPX-351 (Cytarabine and Daunorubicin) Liposome for Injection Versus Conventional Cytarabine Plus Daunorubicin in Older Patients With Newly Diagnosed Secondary Acute Myeloid Leukemia. J Clin Oncol (2018) 36(26):2684-92. doi: 10.1200/JCO.2017.77.6112

6. Zhang Q, Bykov VJN, Wiman KG, Zawacka-Pankau J. APR-246 Reactivates Mutant P53 by Targeting Cysteines 124 and 277. Cell Death Dis (2018) 9 (5):439. doi: 10.1038/s41419-018-0463-7

7. Cluzeau T, Sebert M, Rahmé R, Cuzzubbo S, Walter-Petrich A, Lehmann-Che J, et al. APR-246 Combined With Azacitidine (AZA) in TP53 Mutated Myelodysplastic Syndrome (MDS) and Acute Myeloid Leukemia (AML). A Phase 2 Study by the Groupe Francophone Des Myélodysplasies (GFM). Blood (2019) 134(Supplement_1):677. doi: 10.1182/blood-2019-125579

8. Maslah N, Salomao N, Drevon L, Verger E, Partouche N, Ly P, et al. Synergistic Effects of PRIMA-1 ${ }^{\text {met }}$ (APR-246) and 5-Azacitidine in TP53Mutated Myelodysplastic Syndromes and Acute Myeloid Leukemia. Haematologica (2020) 105(6):1539-51. doi: 10.3324/haematol.2019.218453

9. Sowrds RT, Coutre S, Maris MB, Zeidner JF, Foran JM, Cruz J, et al. Pevonedistat, a First-in-Class NEDD8-Activating Enzyme Inhibitor, Combined With Azacytidine in Patients With AML. Blood (2018) 131 (13):1415-24. doi: 10.1182/blood-2017-09-805895

\section{ETHICS STATEMENT}

All procedures were in accordance with the ethical standards of the institutional research committee. The patients/participants provided their written informed consent to participate in this study.

\section{AUTHOR CONTRIBUTIONS}

$\mathrm{RL}$ and AMar contributed equally to the figures and writing. AMan, $\mathrm{SB}$, and $\mathrm{EH}$ reviewed the manuscript. AV provided guidance, and AP wrote the manuscript and provided critical review. SH and LR provided critical review. All authors contributed to the article and approved the submitted version.

\section{FUNDING}

These studies were supported by the grant from the "Associazione Italiana per la Ricerca sul Cancro (AIRC)", START-UP Grant n. 20456 to AP.

10. Restifo NP, Dudley ME, Rosenberg SA. Adoptive Immunotherapy for Cancer: Harnessing the T Cell Response. Nat Rev Immunol (2012) 12(4):269-81. doi: $10.1038 /$ nri3191

11. Maude SL, Frey N, Shaw PA, Aplenc R, Barrett DM, Bunin NJ, et al. Chimeric Antigen Receptor T Cells for Sustained Remissions in Leukemia. N Engl J Med (2014) 371(16):1507-17. doi: 10.1056/NEJMoa1407222

12. Kalos M, Levine BL, Porter DL, Katz S, Grupp SA, Bagg A, et al. T Cells With Chimeric Antigen Receptors Have Potent Antitumor Effects and Can Establish Memory in Patients With Advances Leukemia. Sci Transl Med (2011) 3 (95):95ra73. doi: 10.1126/scitranslmed.3002842

13. Porter DL, Hwang W-T, Frey NV, Lacey SF, Shaw PA, Loren AW, et al. Chimeric Antigen Receptor T Cells Persist and Induce Sustained Remissions in Relapsed Refractory Chronic Lymphocytic Leukemia. Sci Transl Med (2015) 7(303):303ra139. doi: 10.1126/scitranslmed.aac5415

14. Ciurea SO, Labopin M, Socie G, Volin L, Passweg J, Chevallier P, et al. Relapse and Survival After Transplantation for Complex Karyotype Acute Myeloid Leukemia: A Report From the Acute Leukemia Working Party of the European Society for Blood and Marrow Transplantation and the University of Texas MD Anderson Cancer Center. Cancer (2018) 124 (10):2134-41. doi: 10.1002/cncr.31311

15. Pasquini MC, Zhang MJ, Medeiros BC, Armand P, Hu ZH, Nishihori T, et al. Hematopoietic Cell Transplantation Outcomes in Monosomal Karyotype Myeloid Malignancies. Biol Blood Marrow Transplant (2016) 22(2):248-57. doi: 10.1016/j.bbmt.2015.08.024

16. Middeke JM, Herold S, Rücker-Braun E, Berdel WE, Stelljes M, Kaufmann M, et al. TP53 Mutation in Patients With High-Risk Acute Myeloid Leukaemia Treated With Allogeneic Haematopoietic Stem Cell Transplantation. Br J Haematol (2016) 172(6):914-22. doi: 10.1111/bjh.13912

17. Martelli MF, Di Ianni M, Ruggeri L, Pierini A, Falzetti F, Carotti A, et al. "Designed" Grafts for HLA-Haploidentical Stem Cell Transplantation. Blood (2014) 123:967-73. doi: 10.1182/blood-2013-10-531764

18. Marra A, Ruggeri L, Carotti A, Venanzi A, Falzetti F, Terenzi A, et al. HLAHaploidentical Transplantation With Regulatory and Conventional T Cell Immunotherapy Eradicates Acute Myeloid Leukemia With High-Risk Cytogenetics. Eur Hematol Assoc (EHA) Congress (2020), EHA-3473.

19. Mrózek K. Cytogenetic, Molecular Genetic, and Clinical Characteristics of Acute Myeloid Leukemia With a Complex Karyotype. Semin Oncol (2008) 35:365-77. doi: 10.1053/j.seminoncol.2008.04.007 
20. Grimwade D, Hills RK, Moorman AV, Walker H, Chatters S, Goldstone AH, et al. Refinement of Cytogenetic Classification in Acute Myeloid Leukemia: Determination of Prognostic Significance of Rare Recurring Chromosomal Abnormalities Among 5876 Younger Adult Patients Treated in the United Kingdom Medical Research Council Trials. Blood (2010) 116:354-65. doi: 10.1182/blood-2009-11-254441

21. Breems DA, Van Putten WL, De Greef GE, Van Zelderen-Bhola SL, GerssenSchoorl KB, Mellink CH, et al. Monosomal Karyotype in Acute Myeloid Leukemia: A Better Indicator of Poor Prognosis Than a Complex Karyotype. J Clin Oncol (2008) 26:4791-7. doi: 10.1200/JCO.2008.16.0259

22. Mrozek K, Esifeld AK, Kohlschmidt J, Carroll AJ, Walker CJ, Nicolet D, et al. Complex Karyotype in De Novo Acute Myeloid Leukemia: Typical and Atypical Subtypes Differ Molecularly and Clinically. Leukemia (2019) 33:1620-34. doi: 10.1038/s41375-019-0390-3

23. Cavelier C, Didier C, Prade N, Mansat-De Mas V, Manenti S, Recher C, et al. Constitutive Activation of the DNA Damage Signaling Pathway in Acute Myeloid Leukemia With Complex Karyotype: Potential Importance for Checkpoint Targeting Therapy. Cancer Res (2009) 69(22):8652-61. doi: 10.1158/0008-5472.CAN-09-0939

24. Moison C, Lavallée V-P, Thiollier C, Lehnertz B, Boivin I, Mayotte N, et al. Complex Karyotype AML Displays G2/M Signature and Hypersensitivity to PLK1 Inhibition. Blood Adv (2019) 3(4):552-63. doi: 10.1182/bloodadvances.2018028480

25. Leung GMK, Zhang C, Ng NKL, Yang N, Lam SSY, Au CH, et al. Distinct Mutation Spectrum, Clinical Outcome and Therapeutic Responses of Typical Complex/Monosomy Karyotype Acute Myeloid Leukemia Carrying TP53 Mutations. Am J Hematol (2019) 94(6):650-7. doi: 10.1002/ajh.25469

26. Rucker FG, Dolnik A, Blätte TJ, Teleanu V, Ernst A, Thol F, et al. Chromotripsis Linked to TP53 Alteration, Cell Cycle Impairment, and Dismal Outcome in Acute Myeloid Leukemia With Complex Karyotype. Haematologica (2018) 103(1):e17-20. doi: 10.3324/haematol.2017.180497

27. McNerney ME, Godley LA, Le Beau MM. Therapy-Related Myeloid Neopalsms: When Genetics and Environment Collide. Nat Rev Cancer (2017) 17(9):513-27. doi: 10.1038/nrc.2017.60

28. Lavallée V-P, Gendron P, Lemieux S, D'Angelo G, Hébert J, Sauvageau G. EVI1Rearranged Acute Myeloid Leukemias are Characterized by Distinct Molecular Alterations. Blood (2015) 125(1):140-3. doi: 10.1182/blood-2014-07-591529

29. Lugthart S, Groschel S, Berloo HB, Kayser S, Valk PJM, Van Zelderen-Bhola SL, et al. Clinical, Molecular, and Prognostic Significance of WHO Type Inv (3)(Q21q26.2)/T(3;3)(Q21;Q26.2) and Various Other 3q Abnormalities in Acute Myeloid Leukemia. J Clin Oncol (2010) 28(24):3890-8. doi: 10.1200/ JCO.2010.29.2771

30. Vago L, Perna SK, Zanussi M, Mazzi B, Barlassina C, Stanghellini MT, et al. Loss of Mismatched HLA in Leukemia After Stem-Cell Transplantation. N Engl J Med (2009) 361(5):478-88. doi: 10.1056/NEJMoa0811036

31. Khalil DN, Smith EL, Brentjens RJ, Wolchok JD. The Future of Cancer Treatment: Immunomodulation, CARs and Combination Immunotherapy. Nat Rev Clin Oncol (2016) 13(6):394. doi: 10.1038/nrclinonc.2016.65

32. Curti A, Ruggeri L, Parisi S, Bontadini A, Dan E, Motta MR, et al. Larger Size of Donor Alloreactive NK Cell Repertoire Correlates With Better Response to NK Cell Immunotherapy in Elderly Acute Myeloid Leukemia Patients. Clin Cancer Res (2016) 22(8):1914-21. doi: 10.1158/1078-0432.CCR-15-1604

33. Fehniger TA, Miller JS, Stuart RK, Cooley S, Salhotra A, Curtsinger J, et al. A Phase 1 Trial of CNDO-109-Activated Natural Killer Cells in Patients With High-Risk Acute Myeloid Leukemia. Biol Blood Marrow Transplant (2018) 24 (8):1581-9. doi: 10.1016/j.bbmt.2018.03.019

34. Ciurea SO, Schafer JR, Bassett R, Denman CJ, Cao K, Willis D, et al. Phase 1 Clinical Trial Using Mbil21 Ex Vivo-Expanded Donor-Derived NK Cells After Haploidentical Transplantation. Blood (2017) 130(16):1857-68. doi: 10.1182/blood-2017-05-785659

35. Stern M, Passweg JR, Meyer-Monard S, Esser R, Tonn T, Soerensen J, et al. Preemptive Immunotherapy With Purified Natural Killer Cells After Haploidentical SCT: A Prospective Phase II Study in Two Centers. Bone Marrow Transplant (2013) 48(3):433-8. doi: 10.1038/bmt.2012.162

36. Introna M, Pievani A, Borleri G, Capelli C, Algarotti A, Micò C, et al. Repeated Infusions of Donor-Derived Cytokine-Induced Killer Cells in Patients Relapsing After Allogeneic Stem Cell Transplantation: A Phase I Study. Haematologica (2007) 92(7):952-9. doi: 10.3324/haematol.11132

37. Introna M, Borleri G, Conti E, Franceschetti M, Barbui AM, Broady R, et al. Feasibility and Safety of Adoptive Immunotherapy With CIK Cells After Cord
Blood Transplantation. Biol Blood Marrow Transplant (2010) 16(11):1603-7. doi: 10.1016/j.bbmt.2010.05.015

38. Rettinger E, Huenecke S, Bonig H, Merker M, Jarisch A, Soerensen J, et al. Interleukin-15-Activated Cytokine-Induced Killer Cells May Sustain Remission in Leukemia Patients After Allogeneic Stem Cell Transplantation: Feasibility, Safety and First Insights on Efficacy. Haematologica (2016) 101(4):e153-6. doi: 10.3324/haematol.2015.138016

39. Linn YC, Yong H-X, Niam M, Lim T-J, Chu S, Choong A, et al. A Phase I/II Clinical Trial of Autologous Cytokine-Induced Killer Cells as Adjuvant Immunotherapy for Acute and Chronic Myeloid Leukemia in Clinical Remission. Cytotherapy (2012) 14(7):851-9. doi: 10.3109/14653249.2012.694419

40. Ritchie DS, Neeson PJ, Khot A, Peinert S, Tai T, Tainton K, et al. Persistence and Efficacy of Second Generation CAR T Cell Against the LeY Antigen in Acute Myeloid Leukemia. Mol Ther (2013) 21(11):2122-9. doi: 10.1038/ mt.2013.154

41. Wang QS, Wang Y, Lv H-Y, Han Q-W, Fan H, Guo B, et al. Treatment of CD33-Directed Chimeric Antigen Receptor-Modified T Cells in One Patient With Relapsed and Refractory Acute Myeloid Leukemia. Mol Ther (2015) 23 (1):184-9. doi: 10.1038/mt.2014.164

42. Tasian SK, Kenderian SS, Shen F, Ruella M, Shestova O, Kozlowski M, et al. Optimized Depletion of Chimeric Antigen Receptor T Cells in Murine Xenograft Models of Human Acute Myeloid Leukemia. Blood (2017) 129 (17):2395-407. doi: 10.1182/blood-2016-08-736041

43. Murad JM, Baumeister SH, Werner L, Daley H, Trébéden-Negre H, Reder J, et al. Manufacturing Development and Clinical Production of NKG2D Chimeric Antigen Receptor-Expressing T Cells for Autologous Adoptive Cell Therapy. Cytotherapy (2018). doi: 10.1016/j.jcyt.2018.05.001

44. Tang X, Yang L, Li Z, Nalin AP, Dai H, Xu T, et al. First-in-Man Clinical Trial of CAR NK-92 Cells: Safety Test of CD33-CAR NK-92 Cells in Patients With Relapsed and Refractory Acute Myeloid Leukemia. Am J Cancer Res (2018) 8 (6):1083-9.

45. Hansrivijit P, Gale RP, Barrett J, Ciurea SO. Cellular Therapy for Acute Myeloid Leukemia - Current Status and Future Prospects. Blood Rev (2019) 37:1100578. doi: 10.1016/j.blre.2019.05.002

46. Stringaris K, Barrett AJ. The Importance of Natural Killer Cell Killer Immunoglobulin- Like Receptor-Mismatch in Transplant Outcomes. Curr Opin Hematol (2017) 24(6):489-95. doi: 10.1097/MOH.0000000000000384

47. Ruggeri L, Capanni M, Urbani E, Perruccio K, Shlomchik WD, Tosti A, et al. Effectiveness of Donor Natural Killer Cell Alloreactivity in Mismatched Hematopoietic Transplants. Science (2002) 295(5562):2097-100. doi: 10.1126/science.1068440

48. Shimoni A, Labopin M, Lorentino F, Van Lint MT, Koc Y, Gülbas Z, et al. Killer Cell Immunoglobulin-Like Receptor Ligand Mismatching and Outcome After Haploidentical Transplantation With Post-Transplant Cyclophosphamide. Leukemia (2019) 33(1):230-9. doi: 10.1038/s41375-018-0170-5

49. Costello RT, Sivori S, Marcenaro E, Lafage-Pochitaloff M, Mozziconacci M-J, Reviron D, et al. Defective Expression and Function of Natural Killer CellTriggering Receptors in Patients With Acute Myeloid Leukemia. Blood (2002) 99(10):3661-7. doi: 10.1182/blood.V99.10.3661

50. Stringaris K, Sekine T, Khoder A, Alsuliman A, Razzaghi B, Sargeant R, et al. Leukemia-Induced Phenotypic and Functional Defects in Natural Killer Cells Predict Failure to Achieve Remission in Acute Myeloid Leukemia. Haematologica (2014) 99(5):836-47. doi: 10.3324/haematol.2013.087536

51. Miller JS, Soignier Y, Panoskaltsis-Mortari A, McNearney SA, Yun GH, Fautsch SK, et al. Successful Adoptive Transfer and In Vivo Expansion of Human Haploidentical NK Cells in Patients With Cancer. Blood (2005) 105 (8):3051-7. doi: 10.1182/blood-2004-07-2974

52. Benyunes MC, Massumoto C, York A, Higuchi CM, Buckner CD, Thompson JA, et al. Interleukin-2 With or Without Lymphokine-Activated Killer Cells as Consolidative Immunotherapy After Autologous Bone Marrow Transplantation for Acute Myelogenous Leukemia. Bone Marrow Transplant (1993) 12(2):159-63.

53. Wang H, Cao F, Li J, Li Y, Liu X, Wang L, Liu Z, et al. Homing of CytokineInduced Killer Cells During the Treatment of Acute Promyelocytic Leukemia. Int J Hematol (2014) 100(2):165-70. doi: 10.1007/s12185-014-1618-7

54. Fan M, Li M, Gao L, Geng S, Wang J, Wang Y, et al. Chimeric Antigen Receptors for Adoptive T Cell Therapy in Acute Myeloid Leukemia. J Hematol Oncol (2017) 10(1):151. doi: 10.1186/s13045-017-0519-7 
55. Mardiros A, Dos Santos C, McDonald T, Brown CE, Wang X, Budde LE, et al. T Cells Expressing CD123-Specific Chimeric Antigen Receptors Exhibit Specific Cytolytic Effector Functions and Antitumor Effects Against Human Acute Myeloid Leukemia. Blood (2013) 122(18):3138-48. doi: 10.1182/blood2012-12-474056

56. Jetani H, Garcia-Cadenas I, Nerreter T, Thomas S, Rydzek J, Meijide JB, et al. CAR T-Cells Targeting FLT3 Have Potent Activity Against FLT3-ITD+ AML and Act Synergistically With the FLT3-Inhibitor Crenolanib. Leukemia (2018) 32(5):1168-79. doi: 10.1038/s41375-018-0009-0

57. Sommer C, Cheng HY, Nguyen D, Dettling D, Yeung YA, Sutton J, et al. Allogeneic FLT3 CAR T Cells With and Off-Switch Exhibit Potent Activity Against AML and Can Be Depleted to Expedite Bone Marrow Recovery. Mol Ther (2020) 28(10):2237-51. doi: 10.1016/j.ymthe.2020.06.022

58. Liu E, Marin D, Banerjee P, Macapinlac HA, Thompson P, Basar R, et al. Use of CAR-Transduced Natural Killer Cells in CD19-Positive Lymphoid Tumors. N Engl J Med (2020) Feb 6382(6):545-53.

59. Kerbauy LN, Ang S, Liu E, Banerjee PP, Wu Y, Shaim H, et al. Cord Blood NK Cells Engineered to Express a Humanized CD123-Targeted Chimeric Antigen Receptor (CAR) and IL-15 as Off-the-Shelf Therapy for Acute Myeloid Leukemia. Blood (2017) 130:4453. doi: 10.1182/blood.V130.Suppl_1.4453.4453

60. Xie G, Dong H, Liang Y, Dongjoo Ham J, Rizwan R, Chen J. CAR-NK Cells: A Promising Cellular Immunotherapy for Cancer. Ebiomedicine (2020) 59:102975. doi: 10.1016/j.ebiom.2020.102975

61. Williams KM, Hanley P, Grant M, Fortiz MF, Stanojevic M, Ismail M, et al. Complete Remissions Post Infusion of Multiple Tumor Antigen Specific T Cells for the Treatment of High Risk Leukemia and Lymphoma Patients After HCT. Blood (2017) 130:4516. doi: 10.1016/j.jcyt.2017.03.013

62. Ping Y, Liu C, Zhang Y. T-Cell Receptor-Engineered T Cells for Cancer Treatment: Current Status and Future Directions. Protein Cell (2018) 9 (3):254-66. doi: 10.1007/s13238-016-0367-1

63. Johnson LA, Morgan RA, Dudley ME, Cassard L, Yang JC, Hughes MS, et al. Gene Therapy With Human and Mouse T-Cell Receptors Mediates Cancer Regression and Targets Normal Tissues Expressing Cognate Antigen. Blood (2009) 114(3):535-46. doi: 10.1182/blood-2009-03-211714

64. Chapuis AG, Ragnarsson GB, Nguyen HN, Chaney CN, Pufnock JS, Schmitt TM, et al. Transferred WT1-Reactive CD8+ T Cells Can Mediate Antileukemic Activity and Persist in Post-Transplant Patients. Sci Transl Med (2013) 5(174):174ra27. doi: 10.1126/scitranslmed.3004916

65. Jahn L, Hombrink P, Hagedoorn RS, Kester MG, van der Steen DM, Rodriguez T, et al. TCR-Based Therapy for Multiple Myeloma and Other B-Cell Malignancies Targeting Intracellular Transcription Factor BOB1. Blood (2017) 129:1284-95. doi: 10.1182/blood-2016-09-737536

66. Gupta V, Tallman MS, He W, Logan BR, Copelan E, Gale RP, et al. Comparable Survival After HLA-Well-Matched Unrelated or Matched Sibling Donor Transplantation for Acute Myeloid Leukemia in First Remission With Unfavorable Cytogenetics at Diagnosis. Blood (2010) 116 (11):1839-48. doi: 10.1182/blood-2010-04-278317

67. Di Bartolomeo P, Santarone S, De Angelis G, Picardi A, Cudillo L, Cerretti R, et al. Haploidentical, Unmanipulated, G-CSF-Primed Bone Marrow Transplantation for Patients With High-Risk Hematologic Malignancies. Blood (2013) 121(5):849-57. doi: 10.1182/blood-2012-08-453399

68. Chiusolo P, Bug G, Olivieri A, Brune M, Mordini N, Alessandrino PE, et al. A Modified Post-Transplant Cyclophosphamide Regimen, for Unmanipulated Haploidentical Marrow Transplantation, in Acute Myeloid Leukemia: A Multicenter Study. Biol Blood Marrow Transplant (2018) 24(6):1243-9. doi: 10.1016/j.bbmt.2018.01.031

69. Devillier R, Legrand F, Rey J, Castagna L, Fürst S, Granata A, et al. HLA-Matched Sibling Versus Unrelated Versus Haploidentical Related Donor Allogeneic Hematopoietic Stem Cell Transplantation for Patients Aged Over 60 Years With Acute Myeloid Leukemia: A Single-Center Donor Comparison. Biol Blood Marrow Transplant (2018) 24(7):1449-54. doi: 10.1016/j.bbmt.2018.02.002

70. Ciurea SO, Mulanovich V, Saliba RM, Bayraktar UD, Jiang Y, Bassett R, et al. Improved Early Outcomes Using a T Cell Replete Graft Compared With T Cell Depleted Haploidentical Hematopoietic Stem Cell Transplantation. Biol Blood Marrow Transplant (2012) 18:1835-44. doi: 10.1016/j.bbmt.2012.07.003

71. Shelikhova L, Ilushina M, Shekhovtsova Z, Shasheleva D, Khismatullina R, Kurnikova E, et al. $\alpha \beta$ T Cell-Depleted Haploidentical Hematopoietic Stem Cell Transplantation Without Antithymocyte Globulin in Children With
Chemorefractory Acute Myelogenous Leukemia. Biol Blood Marrow Transplant (2019) 25(5):e179-82. doi: 10.1016/j.bbmt.2019.01.023

72. Maschan M, Shelikhova L, Ilushina M, Shekhovtsova Z, Khismatullina R, Kurnikova E, et al. Outcome of $\alpha \beta$ T Cell-Depleted Transplantation in Children With High-Risk Acute Myeloid Leukemia, Grafted in Remission. Bone Marrow Transplant (2020) 55(1):256-9. doi: 10.1038/s41409-019-0531-3

73. Locatelli F, Merli P, Pagliara D, Li Pira G, Falco M, Pende D, et al. Outcome of Children With Acute Leukemia Given HLA-Haploidentical HSCT After $\alpha \beta$ T-Cell and B-Cell Depletion. Blood (2017) 130(5):677-85. doi: 10.1182/blood2017-04-779769

74. Bertaina A, Zecca M, Buldini B, Sacchi N, Algeri M, Saglio F, et al. Unrelated Donor vs HLA-Haploidentical $\alpha / \beta$ T-Cell and B-Cell-Depleted HSCT in Children With Acute Leukemia. Blood (2018) 132(24):2594-607. doi: 10.1182/ blood-2018-07-861575

75. Bleakley M, Heimfeld S, Loeb KR, Jones LA, Chaney C, Seropian S, et al. Outcomes of Acute Leukemia Patients Transplanted With Naïve T Cell-Depleted Stem Cell Grafts. J Clin Investig (2015) 125(7):2677-89. doi: 10.1172/JCI81229

76. Pierini A, Ruggeri L, Carotti A, Falzetti F, Saldi S, Terenzi A, et al. Haploidentical Age-Adapted Myeloablative Transplant and Regulatory and Effector T Cells for Acute Myeloid Leukemia. Blood Adv (2021) 5):1199-208. doi: 10.1182/bloodadvances.2020003739

77. Huang XJ, Liu DH, Liu KY, Xu LP, Chen H, Han W, et al. Treatment of Acute Leukemia With Unmanipulated HLA-Mismatched/Haploidentical Blood and Bone Marrow Transplantation. Biol Blood Marrow Transplant (2009) 15:25765. doi: 10.1016/j.bbmt.2008.11.025

78. Sugita J. HLA-Haploidentical Stem Cell Transplantation Using Posttransplant Cyclophosphamide. Int J Hematol (2019) 110:30-8. doi: 10.1007/s12185-01902660-8

79. Raiola AM, Dominietto A, Ghiso A, Di Grazia C, Lamparelli T, Gualandi F, et al. Unmanipulated Haploidentical Bone Marrow Transplantation and Posttransplantation Cyclophosphamide for Hematologic Malignancies After Myeloablative Conditioning. Biol Blood Marrow Transplant (2013) 19:117-22. doi: 10.1016/j.bbmt.2012.08.014

80. Peccatori J, Forcina A, Clerici D, Crocchiolo R, Vago L, Stanghellini MT, et al. Sirolimus-Based Graft-Versus-Host Disease Prophylaxis Promotes the In Vivo Expansion of Regulatory T Cells and Permits Peripheral Blood Stem Cell Transplantation From Haploidentical Donors. Leukemia (2015) 29:396405. doi: 10.1038/leu.2014.180

81. Brunstein CG, Fuchs EJ, Carter SL, Karanes C, Costa LJ, Wu J, et al. Alternative Donor Transplantation After Reduced Intensity Conditioning: Results of Parallel Phase 2 Trials Using Partially HLA-Mismatched Related Bone Marrow or Unrelated Double Umbilical Cord Blood Grafts. Blood (2011) 118(2):282-8. doi: 10.1182/blood-2011-03-344853

82. Aversa F, Pierini A, Ruggeri L, Martelli MF, Velardi A. The Evolution of T Cell Depleted Haploidentical Transplantation. Front Immunol (2019) 10:2769. doi: 10.3389/fimmu.2019.02769

83. Grimm J, Jentzsch M, Bill M, Goldmann K, Schulz J, Niederwieser D, et al. Prognostic Impact of the ELN2017 Risk Classification in Patients With AML Receiving Allogeneic Transplantation. Blood Adv (2020) 4(16):3864-74. doi: 10.1182/bloodadvances.2020001904

Conflict of Interest: The authors declare that the research was conducted in the absence of any commercial or financial relationships that could be construed as a potential conflict of interest.

Publisher's Note: All claims expressed in this article are solely those of the authors and do not necessarily represent those of their affiliated organizations, or those of the publisher, the editors and the reviewers. Any product that may be evaluated in this article, or claim that may be made by its manufacturer, is not guaranteed or endorsed by the publisher.

Copyright (c) 2021 Limongello, Marra, Mancusi, Bonato, Hoxha, Ruggeri, Hui, Velardi and Pierini. This is an open-access article distributed under the terms of the Creative Commons Attribution License (CC BY). The use, distribution or reproduction in other forums is permitted, provided the original author(s) and the copyright owner(s) are credited and that the original publication in this journal is cited, in accordance with accepted academic practice. No use, distribution or reproduction is permitted which does not comply with these terms. 